\title{
KEWENANGAN KOMISI PEMILIHAN UMUM DALAM MENGAKTIFKAN KEMBALI ANGGOTA KOMISI PEMILIHAN UMUM
}

\author{
Achmadudin Rajab \\ Badan Keahlian DPR RI, Jakarta \\ achmadudin.rajab@gmail.com
}

\begin{abstract}
Abstrak
Penulisan ini bertujuan untuk menganalisis Putusan PTUN No. 82/G/2020/PTUN.JKT yang membatalkan Kepres No. 34/P Tahun 2020. Begitu juga, menganalisis kewenangan KPU dalam menerbitkan Surat Keputusan Komisi Pemilihan Umum Nomor 663/SDM.13-SD/05KPU/VII2020 yang mengaktifan kembali anggota Komisi Pemilihan Umum. Kedua hal tersebut merupakan tujuan dari tulisan ini karena seperti diketahui bahwa belum lama ini telah mengeluarkan Surat Keputusan KPU No. 663/SDM.13SD/05KPU/VII2020 untuk mengaktifkan kembali anggota Komisi Pemilihan Umum yang sejatinya telah diberhentikan melalui Putusan DKPP Nomor 317-PKEDKPP/X/2019. Pengaktifan kembali penyelenggara pemilihan umum di tingkat pusat dalam hal ini KPU RI bukanlah salah satu kewenangan yang dimiliki oleh KPU begitu juga kewenangan untuk mengkoreksi kembali subtansi dari putusan DKPP oleh PTUN walaupun yang diuji dalam hal ini yakni keputusan Presiden sebagai tindak lanjut dari putusan DKPP. Karena hal ini secara tidak langsung bertentangan dengan sifat putusan DKPP yang final dan mengikat karena menjadi dapat dikoreksi. Untuk itu urgensi tulisan ini adalah untuk mengkaji masing-masing produk hukum ini dari sisi tinjauan yuridis. Mekanisme yang dilakukan adalah melalui penelitian yuridis normatif. Adapun berdasarkan hasil pembahasan diketahui bahwa Putusan PTUN No. 82/G/2020/PTUN.JKT yang membatalkan Kepres No. 34/P Tahun 2020 secara tidak langsung telah mengoreksi Putusan DKPP Nomor 317-PKE-DKPP/X/2019. Sedangkan kewenangan Komisi Pemilihan Umum untuk mengaktifkan kembali komisioner Komisi Pemilihan Umum melalui Surat Keputusan KPU No. 663/SDM.13-SD/05KPU/VII2020 tidak mempunyai landasan hukum yang jelas dalam Undang-Undang Nomor 7 Tahun 2017 tentang Peilihan Umum.
\end{abstract}

Kata kunci: Kewenangan; Penyelenggara Pemilihan Umum; Pengaktifan Kembali 


\title{
KOMISI PEMILIHAN UMUM AUTHORITY TO REACTIVATE THE KOMISI PEMILIHAN UMUM COMMISSION
}

\begin{abstract}
Purpose of these writing is to analyze The Administrative Court Decision Number 82/G/2020/PTUN.JKT that invalidates the Presidential Decree Number 34 /P Year 2020. Also to analyzing the Komisi Pemilihan Umum Authority in issuing a letter of decree number 663/SDM.13-SD/05KPU/VII2020 to reactivate the the members of Komisi Pemilihan Umum Commission. The two things is the goal of this writing because as we noticed that recently Komisi Pemilihan Umum has issued a letter of decree number 663/SDM.13-SD/05KPU/VII2020 to reactivate the members the members of Komisi Pemilihan Umum Commission That should have Been discharged by the DKPP Decisions Number 317-PKE-DKPP/X/2019. The authority to reactivate the election commission in the central level in this case for KPU RI was not one of authority that KPU have, nor the authority to changed the substance of DKPP decision by PTUN eventhough the one that being tested is the presidential decree as the follow-up to the DKPP Decision. It because the resultd is contrary to the level of DKPP Decision which is final and binding because became able to be corrected. For that urgency this writing is to analyze each of legal products with the yuridical review poin of view. A mechanism of this writings is done through yuridical normative research. As for the outcome of his discussions known that The Administrative Court Decision Number 82/G/2020/PTUN.JKT that invalidates the Presidential Decree Number 34 /P Year 2020 is indirectly have revise the DKPP Decisions Number 317-PKE-DKPP/X/2019. As for the Komisi Pemilihan Umum Authority to reactivate the the members of Komisi Pemilihan Umum Commission by letter of decree number 663/SDM.13-SD/05KPU/VII2020 is don't have a clear legal basis in The Law Number 7 Year 2017 of General Election.
\end{abstract}

Keywords: Authority; Election Commission; Reactive. 
e-ISSN : 2621-4105

\section{A. PENDAHULUAN}

Dewan Kehormatan Penyelengara Pemilu Republik Indonesia (DKPP) merupakan salah satu dari satu kesatuan penyelenggaran Pemilihan Umum (Pemilu). Sebagai salah satu dari ketiga unsur penyelenggara Pemilu tersebut, DKPP memiliki fungsi yang paling berbeda sesuai dengan perintah undang-undang. Dalam Undang-Undang Nomor 7 Tahun 2017 tentang Pemilihan Umum (UU No. 7 Tahun 2017), DKPP dikonstruksikan sebagai suatu instansi permanen yang memiliki tugas untuk menangani pelanggaran kode etik penyelenggara Pemilu. Penegakan pelanggaran etika di DKPP pun berbeda dengan lembaga penegak etik lainnya yang umumnya dilaksanakan secara tertutup. Persidangan DKPP dilaksanakan secara terbuka dan para pihak baik itu pengadu, teradu, dan pihakpihak terkait lainnya dapat turut serta dalam mengawal persidangan DKPP dari awal hingga akhir.

Sejak awal DKPP merupakan suatu ius constituendum untuk dalam penyelenggaraan Pemilu. Kehadiran DKPP ini menjawab problematika potensi ketidaknetralan penyelenggara Pemilu yang kerap terjadi. Lebih lanjut lagi, ketika Pemilihan Kepala Daerah dan Wakil Kepala Daerah (Pilkada) saat ini pun dilaksanakan juga secara langsung, maka tugas dan tantangan DKPP terlihat. Hal ini dikarenakan pula pelaksanaan Pilkada langsung di Indonesia dilaksanakan dengan sejumlah harapan untuk memperbaiki kehidupan demokrasi di Indonesia. ${ }^{1}$ Tak jarang bahkan tantangan DKPP dalam pelaksanaan Pilkada langsung begitu besar. Hal ini terjadi karena merupakan suatu wujud peralihan dari politik lama yang sentralistik ke politik baru yang polisentris, walaupun dalam aplikasinya masih tidak menghasilkan kesempatan yang sama bagi semua lapisan masyarakat untuk berkiprah di politik lokal. ${ }^{2}$ Oleh karenanya, keberadaan DKPP tidak dapat ditawar-tawar kembali.

Seorang anggota Komisi Pemilihan Umum (KPU) dapat diberhentikan secara tidak hormat sebagaimana diatur dalam Pasal 37 ayat (1) huruf c UU No. 7 Tahun 2017. Adapun salah satu sebab pembehentian tidak hormat tersebut yakni terbukti melanggar sumpah/janji jabatan dan/atau kode etik. ${ }^{3}$ Ketentuan pasal ini tidak berbeda jauh dengan

${ }^{1}$ Pratikno, "Calon Independen, Kualitas Pilkada dan Pelembagaan Parpol”, Jurnal Ilmu Sosial dan Ilmu Politik 10 (3), 2007, hal 417.

${ }^{2}$ Leo Agustino, et.al., "Poltik Lokal di Indonesia: Dari Otokratik Ke Reformasi Poltik”, Jurnal Ilmu Politik 21, 2010, hal 27.

${ }^{3}$ Lihat Pasal 37 ayat (2) huruf b Undang-Undang Nomor 7 Tahun 2017 tentang Pemilihan Umum. 
e-ISSN : 2621-4105

pengaturan dalam undang-undang sebelumnya yakni dalam Pasal 27 ayat (2) huruf b Undang-Undang Nomor 15 Tahun 2011 tentang Penyelenggara Pemilihan Umum (UU No. 15 Tahun 2011). Adapun setelah adanya Putusan Mahkamah Konstitusi Nomor 14/PUU-XI/2013 (Putusan MK No. 14/PUU-XI/2013), kemudian dilakukan penggabungan undang-undang kepemilu termasuk UU No. 15 Tahun 2011 yang kemudian menjadi UU No. 7 Tahun 2017.

Pelanggaran kode etik yang merupakan salah satu alasan pemberhentian secara tidak hormat merupakan kewenangan bagi DKPP untuk menindaklanjutinya. DKPP memiliki mandate yang telah diberikan oleh konstitusi untuk menegakkan pelanggaran kode etik Pemilu. Pasal 22E ayat (5) Undang-Undang Dasar Negara Republik Indonesia Tahun 1945 (UUD NRI Tahun 1945) mengamanatkan bahwa suatu komisi pemisi pemilihan umum harus bersifat nasional, tetap, dan mandiri. Adapun berdasarkan Putusan Mahkamah Konstitusi (MK) Nomor 11/PUU-VIII/2010 mengenai frasa suatu komisi pemisi pemilihan umum tidak merujuk kepada nama lembaga namun kepada fungsi penyelenggaraan Pemilu maka menjaga kemandirian atau netralitas bukan hanya kewajiban dari KPU namun juga bagi keseluruhan penyelenggara Pemilu baik itu KPU, Badan Pengawas Pemilihan Umum (Bawaslu), dan DKPP.

Achmadudin Rajab dalam kajiannya yang mengkaji mengenai kekuatan putusan DKPP sudah pernah menggambarkan betapa besar keberadaan produk hukum putusan DKPP dalam dunia kepemiluan. Salah satu kelebihan dari lembaga DKPP yang hadir sebagai amanat UU No. 15 Tahun 2011 yakni mejadi solusi dari persoalan etika kepemiluan setelah sebelumnya penegakan etika pemilu dilakukan oleh lembaga ad hoc yakni Dewan Kehormatan Komisi Pemilihan Umum (DK-KPU). ${ }^{4}$ Melalui format lembaga yang permanen DKPP bukan hanya diisi oleh unsur-unsur yang lebih objektif dibandingkan sebelumnya yang diisi sebagian besar oleh KPU, melainkan juga produk hukumnya yakni putusan dan bukan seperti sebelumnya yakni rekomendasi. Adapun dalam penelitian ini fokus utamanya yakni putusan DKPP yang sifatnya final dan mengikat terkadang digunakan oleh lembaga tersebut untuk menghasilkan putusan yang diluar kewenangannya dalam hal ini restorative justice. Dalam penelitian ini belum diketahui bahwa ternyata putusan DKPP dapat pula disimpangi keberlakuannya melalui

\footnotetext{
${ }^{4}$ Achmadudin Rajab, "Kekuatan Putusan DKPP Sebagai Peradilan Etik Dalam Kerangka Restoratif Justice Pasca Putusan Mahkamah Konstitusi Nomor 115/PHPU.D-XI/2013 Dan Putusan Mahkamah Konstitusi Nomor 31/PUU-XI/2013”, Jurnal Etika dan Pemilu 1 (2), 2015, hal 98.
} 
e-ISSN : 2621-4105

pola seperti yang terjadi dalam perkara etika yang terjadi pada komisioner KPU RI yakni Evi Novida Ginting Manik. Dalam penelitian ini justru kepatuhan terhadap putusan DKPP yang bersifat final dan mengikat ini yang disalahgunakan untuk menangani halhal yang diluar kewenangan lembaga tersebut.

R. Nazriyah dalam kajiannya juga pernah mengkaji mengenai Pemberhentian Antar Waktu Anggota KPU dengan menggunakan pisau analisis Putusan MK No. 80/PUUIX/2011. Dalam Putusan MK tersebut, MK mengabulkan permohonan Pemohon sehingga menghapus frasa "dengan alasan yang dapat diterima" dalam Pasal 27 ayat (1) huruf b dan menghapus Pasal 27 ayat (3) mengenai kewajiban mengembalikan uang kehormatan sebanyak 2 (dua) kali dari yang diterima. Kajian ini menggunakan studi kasus dimana pada waktu itu Andi Nurpati yang merupakan anggota KPU periode 2007-2012 berniat mengundurkan diri dari KPU untuk bergabung dengan partai demokrat. ${ }^{5}$ Adapun Andi Nurpati sebagai seorang komisioner KPU RI yang menujukkan keberpihakan kepada partai tertentu jelas merupakan tindakan yang melanggar hukum dan tidak sesuai dengan etika kepemiluan. Begitu juga studi kasus anggota KPU Bogor atas nama Tugiman yang ingin berhenti dari KPU namun merasa terkendalan dengan frasa "dengan alasan yang dapat diterima” dalam Pasal 27 ayat (1) huruf b UU No. 15 Tahun 2011. Adapun amanat Putusan MK No. 80/PUU-IX/2011 sudah ditindaklanjuti dalam Pasal 37 UU No. 7 Tahun 2017. Perlu diketahui bahwa kajian ini masih menggunakan dasar UU No. 15 Tahun 2011 padahal sejak adanya UU No. 7 Tahun 2017 maka UU No. 15 Tahun 2011 telah dicabut dan dinyatakan tidak berlaku. Namun demikian, yang dapat dipelajari dari kajian ini yakni keberpihakan penyelenggara Pemilu terhadap partai politik seperti yang dilakukan oleh Andi Nurpati telah menambah pentingnya pembentukan lembaga etik kepemiluan. Namun demikian, kehadiran DKPP sejak tahun 2012 tidak serta merta menjadikan penyelenggara Pemilu secara disiplin menjaga dirinya dari potensi pelanggaran kode etik penyelenggara Pemilu. Tantangan menjaga kemandirian penyelenggara Pemilu merupakan tantangan besar bagi lembaga DKPP yang belum terjawab sejak kehadirannya hingga saat ini.

Lulu Kukuh Sekartadi dalam kajiannya juga membahas mengenai peran putusan DKPP yang memiliki dampak yakni mengubah keputusan KPU Provinsi Jawa Timur.

${ }^{5}$ R. Nazriyah, "Pemberhentian Antar Waktu Anggota KPU (Analisis Putusan Mahkamah Konstitusi No. 80/PUU-IX/2011)”, Jurnal Konstitusi 9 (4), 2012, hal. 772. 
e-ISSN : 2621-4105

Bahwa lembaga DKPP seperti dipelajari sebelumnya perannya penting karena penyelenggara Pemilu terkadang integritasnya bermasalah. Adapun dalam kajian ini dibahas mengenai lembaga DKPP yang justeru putusannya yang bersifat final dan mengikat secara langsung mengubah keputusan KPU Provinsi Jawa Timur. Hal ini sangat disayangkan, karena sepatutnya DKPP hanya bertindak dalam hal penegakan etika saja. Namun dalam Putusan DKPP No. 74/DKPP-PKE-II/2013 yang dibahas dalam kajian ini ternyata putusan DKPP mengubah persoalan pencalonan bakal pasangan calon Khofifah Indar Parawansa dan Herman Suryadi Sumawiredja di Pilkada Provinsi Jawa Timur tahun 2013 yang semula tidak dietetapkan sebagai pasangan calon. ${ }^{6}$ Dalam kajian ini dapat diketahui bahwa seharusnya penegakan etika kepemiluan tidak dipengaruhi oleh tahapan pemilu, karena konteks penegakan etika kepemiluan adanya bagi pribadi penyelenggara Pemilu. Kajian ini lebih fokus mendalami penyimpangan putusan DKPP dalam perkara ini dan pada waktu itu tidak ada penolakan terhadap putusan DKPP tersebut.

Putusan DKPP yang diluar dari kewenangannya jika menggunakan konstruksi berfikir Putusan MK 115/PHPU.D-XI/2013, dimana MK menyatakan bahwa hanya putusan DKPP yang bersifat etika saja yang wajib ditindaklanjuti, maka sudah wajar bilamana timbul penolakan terhadap tindak lanjut putusan DKPP tersebut. Hal yang menarik kemudian ketika muncul penolakan terhadap putusan DKPP yang justru murni terkait dengan persoalan etika kepemiluan. Hal ini terjadi dalam Putusan DKPP Nomor 317-PKE-DKPP/X/2019 yang pada pokoknya menjatuhkan sanksi pemberhentian tetap terhadap Evi Novida Ginting Manik dari posisi sebagai komisioner KPU RI periode 20172022. Kemudian Putusan DKPP Nomor 317-PKE-DKPP/X/2019 tersebut ditindaklanjuti oleh Presiden dengan menerbitkan Keputusan Presiden No. 34/P Tahun 2020 yang berisi keputusan pemberhentian Ibu Evi Novida Ginting Manik. Akan tetapi kemudian Keputusan Presiden No. 34/P Tahun 2020 kemudian digugat ke Pengadilan Tata Usaha Negara (PTUN) dan pada akhirnya melalui Putusan PTUN No. 82/G/2020/PTUN.JKT maka keputusan presiden tersebut dibatalkan. Setelah adanya putusan PTUN tersebut, KPU lalu mengeluarkan surat keputusan nomor 663/SDM.13-

${ }^{6}$ Lulu Kukuh Sekartadi, “Kewenangan Dewan Kehormatan Penyelenggara Pemilu (DKPP) Mengubah Keputusan Komisi Pemilihan Umum (KPU) Provinsi Jawa Timur (Study Kasus Putusan NO.74/DKPP-PKE-II/2013) ', Jurnal IUS 3 (8), 2015, hal 408.

DOI: http://dx.doi.org/10.12345/ius.v3i8.220 
e-ISSN : 2621-4105

SD/05KPU/VII2020 yang kemudian mengaktifkan kembali ibu Evi Novida Ginting Manik sebagai komisoner KPU.

Aktifnya kembali Evi Novida Ginting Manik sebagai komisoner KPU merupakan suatu kondisi kasus yang menarik untuk dibahas. Hal ini dikarenakan sifat putusan DKPP sejak diatur dalam UU No. 15 Tahun 2011 hingga sekarang berdarkan UU No. 7 Tahun 2017 berifat final dan mengikat. Sifat putusan DKPP yang semacam ini serupa dengan Mahkamah Konstitusi Republik Indonesia (MK RI) yang artinya tidak ada mekanisme bandingnya. Ketika lembaga memiliki produk dengan sifat putusan seperti demikian, maka sejatinya tidak ada lagi jalur koreksi terhadap produk hukum tersebut. Apalagi dalam hal penegakan etik penyelenggara Pemilu, aspek kepastian hukum nasib dari penyelenggara pemilu tersebut haruslah jelas dan tegas.

Penelitian ini betujuan untuk menjawab permasalahan yang belum dibahas dalam penelitian sebelum-sebelumnya yakni mengenai ketidakpatuhan terhadap putusan DKPP yang bersifat final dan mengikat yang berdampak terhadap aktif kembalinya penyelenggara Pemilu yang telah diberhentikan. Hal ini merupakan anomali tersendiri karena menurut UU No. 7 Tahun 2017 bersifat final dan mengikat sehingga seharusnya tidak ada lagi upaya hukum yang dilakukan untuk membatalkannya. Begitu juga Ketua KPU RI yang dengan menggunakan dasar Putusan PTUN No. 82/G/2020/PTUN.JKT mengaktifkan kembali komisioner KPU yang telah diberhentikan tersebut. Studi kasus ini merupakan suatu bentuk penelitian yang sangat menarik untuk dibahas. Penelitian ini bertujuan sebagai wujud pembenahan hukum kepemiluan untuk di masa yang akan datang. Begitu juga sekaligus sebagai sumbangan pemikiran untuk penegakan etika kepemiluan yang lebih baik dalam perbaikan undang-undang Pemilu yang saat ini sedang disusun oleh DPR RI.

\section{B. PERMASALAHAN}

Berdasarkan latar belakang yang telah diuraikan di atas maka pokok permasalahan dalam tulisan ini yaitu:

1. Bagaimanakah tinjauan yuridis putusan PTUN No. 82/G/2020/PTUN.JKT yang membatalkan Kepres No. 34/P Tahun 2020?

2. Benarkah kewenangan KPU RI dalam menerbitkan Keputusan KPU No. 663/SDM.13-SD/05KPU/VII2020 yang mengaktifan kembali anggota KPU RI? 
e-ISSN : 2621-4105

\section{METODE PENELITIAN}

Metode dalam tulisan ini, menggunakan bentuk penelitian yakni penelitian Yuridis Normatif ${ }^{7}$. Tipologi penelitian yang digunakan adalah penelitian yang dari segi sifatnya temasuk penelitian eksploratoris (explorative research) adalah "suatu penelitian yang dilakukan untuk memperoleh keterangan, penjelasan dan data mengenai hal-hal yang belum diketahui". Dalam cara pengumpulan datanya dengan mencari bahan kepustakaan yang dilanjutkan membaca, mempelajari, dan meneliti berbagai literatur yang merupakan sumber hukum primer $^{8}$, sumber hukum sekunder ${ }^{9}$, dan sumber hukum tersier ${ }^{10}$, seperti buku, peraturan perundang-undangan, artikel, makalah seminar atau lokakarya, dan lain sebagainya. Obyek penelitan yang dilakukan dalam penulisan ini adalah UU No. 7 Tahun 2017, Putusan PTUN, Putusan DKPP, dan Kepres yang terkait.

Penelitian hukum normatif dengan studi kepustakaan dilakukan untuk mengetahui batasan kewenangan Komisi Pemilihan Umum. Jenis data yang digunakan dalam penelitian ini merupakan data sekunder, yang diperoleh melalui daftar kepustakaan yang berkaitan dengan kepemiluan, kelembagaan KPU dan DKPP, dan Putusan PTUN. Jenis bahan (sumber) hukum yakni pustaka hukum yang dijadikan referensi penulisan dalam penelitian ini, yang diperoleh dari bahan hukum primer yang mempunyai kekuatan mengikat dalam masyarakat, seperti undang-undang dasar, undang-undang, peraturan pemerintah, dan lain sebagainya. Alat pengumpulan data yang dipakai untuk melakukan penelitian adalah dengan penggunaan studi dokumen terhadap ketentuan-ketentuan yang

${ }^{7}$ Dalam penelitian hukum normatif ini, yang diteliti adalah "bahan pustaka atau data sekunder yang mencakup bahan hukum primer, bahan hukum sekunder, dan bahan hukum tertier". Soerjono Soekanto, “Pengantar Penelitian Hukum”, Jakarta: UI-Press, 1986, hal 10.

${ }^{8}$ Bahan hukum primer adalah "bahan pustaka yang berisikan pengetahuan ilmiah yang baru atau mutakhir ataupun pengertian baru tentang fakta yang diketahui maupun mengenai suatu gagasan (ide)". Bahan ini mencakup: (a) buku; (b) kertas kerja konperensi, lokakarya, seminar, simposium, dan seterusnya; (c) laporan penelitian; (d) laporan teknis; (e) majalah; (f) disertasi atau tesis; dan (g) paten. Soerjono Soekanto dan Sri Mamudji, "Penelitian Hukum Normatif: Suatu Tinjauan Singkat", Edisi 1, Cet. V, Jakarta: PT RajaGrafindo Persada, 2001, hal 29.

${ }^{9}$ Bahan hukum sekunder adalah "bahan pustaka yang berisikan informasi tentang bahan primer, yang antara lain mencakup: (a) abstrak; (b) indeks; (c) bibliografi; (d) penerbitan pemerintah; dan (e) bahan acuan lainnya". Ibid.

${ }^{10}$ Bahan hukum tersier atau bahan hukum penunjang, pada dasarnya mencakup: (1) bahan-bahan yang memberikan petunjuk terhadap bahan hukum primer dan bahan hukum sekunder, yang telah dikenal dengan nama bahan acuan bidang hukum atau bahan rujukan bidang hukum. Contohnya adalah abstrak perundang-undangan, bibliografi hukum, direktori pengadilan, ensiklopedia hukum, indeks majalah hukum, kamus hukum, dan seterusnya; dan (2) bahan-bahan primer, sekunder dan penunjang (tersier) di luar bidang hukum, misalnya, yang berasal dari bidang sosiologi, ekonomi, ilmu politik, filsafat dan lain sebagainya, yang oleh para peneliti hukum dipergunakan untuk melengkapi ataupun menunjang data penelitiannya. Ibid., hal. 33 . 
e-ISSN : 2621-4105

terkait dengan dengan kepemiluan, kelembagaan KPU dan DKPP, dan Putusan PTUN. Metode analisis data yang digunakan adalah kuantitatif, dalam suatu penelitian ini dapat didekati dari dua sudut pendekatan, yaitu analisis kuantitatif secara deskriptif, dan analisis kuantitatif secara inferensial, dan untuk penelitian ini dengan analisis kuantitatif yang deskriptif. Bentuk hasil penelitian adalah suatu evaluasi atas problematika pengaturan mengenai dengan kepemiluan, kelembagaan KPU dan DKPP, dan Putusan PTUN. Evaluasi ini berguna untuk perbaikan undang-undang Pemilu yang saat ini sedang disusun oleh DPR serta dapat menjadi masukan bagi ilmu hukum di Indonesia.

\section{HASIL DAN PEMBAHASAN}

\section{Tinjauan Yuridis Putusan PTUN No. 82/G/2020/PTUN.JKT Yang Membatalkan} Kepres No. 34/P Tahun 2020

Putusan PTUN No. 82/G/2020/PTUN.JKT memiliki amar putusan membatalkan Keputusan Presiden No. 34/P Tahun 2020, hal ini bahkan memiliki dampak agar sdr. Evi Novida Ginting yang berdasarkan Putusan DKPP Nomor 317-PKE-DKPP/X/2019 dikembalikan menjadi anggota KPU. Problematika ini muncul menurut penulisan ini karena PTUN menggunakan dasar Pasal 2 Undang-Undang Nomor 9 Tahun 2004 tentang Perubahan Atas Undang-Undang Nomor 5 Tahun 1986 Tentang Peradilan Tata Usaha Negara (UU No. 9 Tahun 2004). Dalam Pasal tersebut dinyatakan bahwa yang tidak termasuk dalam pengertian Keputusan Tata Usaha Negara menurut undang-undang yakni:

1. Keputusan Tata Usaha Negara yang merupakan perbuatan hukum perdata;

2. Keputusan Tata Usaha Negara yang merupakan pengaturan yang bersifat umum;

3. Keputusan Tata Usaha Negara yang masih memerlukan persetujuan;

4. Keputusan Tata Usaha Negara yang dikeluarkan berdasarkan ketentuan Kitab Undang-Undang Hukum Pidana dan Kitab Undang-Undang Hukum Acara Pidana atau peraturan perundang-undangan lain yang bersifat hukum pidana;

5. Keputusan Tata Usaha Negara yang dikeluarkan atas dasar hasil pemeriksaan badan peradilan berdasarkan ketentuan peraturan perundang-undangan yang berlaku; 
e-ISSN : 2621-4105

6. Keputusan Tata Usaha Negara mengenai tata usaha Tentara Nasional Indonesia;

7. Keputusan Komisi Pemilihan Umum baik di pusat maupun di daerah mengenai hasil pemilihan umum.

Jika dilihat dari sisi Pasal 2 UU No. 9 Tahun 2004, memang tidak diatur bahwa apakah mungkin Kepres No. 34/P Tahun 2020 diuji. Namun apakah yang tidak diatur berarti boleh? Penalaran jika tidak diatur berarti boleh dilakukan adalah penalaran dengan terminologi hukum asas legalitas. Dimana tidak dapat seorang warga dihukum tanpa adanya dasar hukum yang melarang. Lebih lanjut, asas legalitas dalam hukum pidana merupakan asas yang sangat fundanmental. Asas legalitas dalam hukum pidana begitu penting untuk menentukan apakah suatu peraturan hukum pidana dapat diberlakukan terhadap tindak pidana yang terjadi. Jadi, apabila terjadi suatu tindak pidana, maka akan dilihat apakah telah ada ketentuan hukum yang mengaturnya dan apakah aturan yang telah ada tersebut dapat diperlakukan terhadap tindak pidana yang terjadi. ${ }^{11}$

Namun dalam penulisan ini mengenai penyikapan adanya Putusan PTUN No. 82/G/2020/PTUN.JKT ini, maka kiranya dapat dianalisis juga dengan penafsiran argumentum a contrario yakni penafsiran undang-undang yang didasarkan atas pengingkaran artinya berlawanan pengertian antara soal yang dihadapi dengan soal yang diatur dalam suatu pasal dalam undang-undang. ${ }^{12}$ Ketika menggunakan penafsiran ini maka berdasarkan analisis dalam penulisan ini justru akan mempersempit perumusan hukum atau perundang-undangan. Penafsiran ini justru akan bertujuan untuk lebih mempertegas adanya kepastian hukum. Ketika menggunakan penafsiran ini menurut penulisan ini justru berbeda lebih tepat dalam melihat Pasal 2 UU No. 9 Tahun 2004. Dalam hal ini ketika Kepres No. 34/P Tahun 2020 dilihat dari penafsiran argumentum a contrario, maka sebetulnya hal ini bukanlah kewenangan Pengadilan TUN.

Dalam penulisan ini mengenai Putusan PTUN No. 82/G/2020/PTUN.JKT, perlu diketahui bahwa substansi yang diuji didalamnya adalah terlalu jauh sampai ke substansi Putusan DKPP Nomor 317-PKE-DKPP/X/2019. Bahkan poin ke 4 dari amar Putusan PTUN tersebut, jika dinilai dari sisi Pasal 458 ayat (11) sampai dengan ayat (13) UU No.

\footnotetext{
${ }^{11}$ Mahrus Ali, "Dasar-Dasar Hukum Pidana”, Jakarta: Sinar Grafika, 2012, hal. 59.

${ }^{12}$ R. Soeroso, "Pengantar Ilmu Hukum”, Jakarta: Sinar Grafika, 2011, hal. 115.
} 
e-ISSN : 2621-4105

7 Tahun 2017, jelas abuse of power atau abus de droit karena PTUN tersebut memberikan rehabilitasi, hal sejatinya merupakan kewenangan DKPP RI yang dijamin oleh UU No. 7 Tahun 2017. Oleh karenanya, jika Putusan PTUN No. 82/G/2020/PTUN.JKT justru terjadi pelanggaran akan kepastian hukum, karena negara melalui UU No. 7 Tahun 2017 sudah menjamin Putusan DKPP bersifat final dan mengikat.

Adapun ketika didalami lebih jauh terkait dengan Putusan DKPP Nomor 317-PKEDKPP/X/2019 menjatuhkan sanksi pemberhentian tetap terhadap Evi Novida Ginting Manik. Berdasarkan pertimbangan Putusan DKPP Nomor 317-PKE-DKPP/X/2019 angka [4.3.3], Evi Novida Ginting Manik yang dalan perkara DKPP disebut disebut sebagai Teradu VII dianggap melakukan pelanggaran kode etik penyelenggara Pemilu karena hal-hal yang pada pokoknya yakni Teradu VII sebagai Koordinator Divisi Teknis Penyelenggaraan dan Logistik Pemilu yang memiliki tanggungjawab etik lebih besar atas ketidakpastian hukum dan ketidakadilan akibat penetapan hasil Pemilu yang tidak dapat dipertanggungjawabkan validitas dan kredibilitasnya. Hal ini penulisan ini adalah jelas dan nyata karena sebagaimana diketahui Pemilu diselenggarakan atas dasar manifestasi prinsip persamaan di muka hukum (equality before the law $)^{13}$ dan kesempatan yang sama dalam pemerintahan (equal opportunity principle). ${ }^{14}$

Lebih lanjut lagi, dalam pertimbangan Putusan DKPP Nomor 317-PKEDKPP/X/2019 selanjutnya dikatakan pula bahwa Teradu VII menjabat Wakil Koordinator Wilayah untuk Provinsi Kalimantan Barat berdasarkan Keputusan KPU Nomor 56/Kpts/KPU/Tahun 2017 tanggal 13 April 2017. Teradu VII berdasarkan Putusan DKPP Nomor 31-PKE-DKPP/III/2019 tanggal 10 Juli 2019 terbukti melanggar Kode Etik dan dijatuhi Sanksi Peringatan Keras serta diberhentikan dari Jabatan Ketua Divisi SDM, Organisasi, Diklat dan Litbang. Teradu VII dikarenakan berulang kali menerima sanksi etik berat dari sejumlah perkara, seharusnya mengambil pelajaran agar bekerja lebih profesional dalam melaksanakan tugas, fungsi dan wewenang sebagai Penyelenggara Pemilu. Teradu VII merupakan leading sector dalam menyusun norma standar yang pasti dan berlaku secara nasional dalam menetapkan perolehan suara dan

\footnotetext{
${ }^{13}$ Lihat Pasal 28D ayat (1) Undang-Undang Dasar Negara Republik Indonesia Tahun 1945.

${ }^{14}$ Dalam Theory of Justice buku karya John Rawls dikemukakan bahwa jabatan-jabatan dan posisiposisi harus dibuka bagi semua orang dalam keadaan di mana adanya persamaan kesempatan yang adil, lihat Pan Mohamad Faiz, "Teori Keadilan John Rawls", Jurnal Konstitusi 6 (1), 2009, hal. 141. Lihat juga Pasal 28D ayat (3) Undang-Undang Dasar Negara Republik Indonesia Tahun 1945.
} 
e-ISSN : 2621-4105

calon terpilih menindaklanjuti Putusan MK tanpa mengorbankan kemurnian suara rakyat yang menjadi tanggungjawab hukum dan etik Teradu VII sebagai penanggungjawab divisi. $^{15}$

Putusan DKPP RI haruslah selalu dianggap benar karena menurut penulisan ini penting kiranya keteguhan dalam kepada hukum positif yang masih belaku dimana hingga saat ini diatur dalam Pasal 458 ayat (13) UU No. 7 Tahun 2017 yang menyatakan bahwa sifat putusan DKPP RI adalah bersifat final dan mengikat. Upaya mengoreksi Putusan DKPP ini menjadi rancu dalam penulisan ini, karena jalur koreksi tersebut tidak disediakan oleh UU No. 7 Tahun 2017. Berbeda dengan Putusan Bawaslu yang menurut Pasal 471 UU No. 7 Tahun 2017 diatur ada mekanisme bandingnya ke PTUN yakni 5 (lima) hari setelah Putusan Bawaslu terkait Sengketa Proses Pemilu dibacakan. Jadi memang secara sah negara telah memberikan mekanismenya yang dijamin oleh undangundang. Hal ini berbeda dengan DKPP RI yang menurut Pasal 458 ayat (13) dibunyikan jelas Putusannya bersifat final dan mengikat, dan dalam UU No. 7 Tahun 2017 sama sekali tidak ada mekanisme koreksi atas putusan DKPP tersebut. Hal ini dalam penulisan ini justru menjadikan bahwa proses ini sudah jelas dan sepatutnya undang-undang harus ditaati karena negara Indonesia adalah negara perundang-undangan sesuai Pasal 1 ayat (3) UUD NRI Tahun 1945 bahwa "Negara Indonesia adalah negara hukum", dan kelaziman sistem civil law yang mengedepankan peraturan yang tertulis.

DKPP RI dengan putusannya yan final dan mengikat juga menurut analisis dalam penulisan ini merupakan suatu bentuk prinsip check and balances dalam penyelenggaraan Pemilu. Seperti diketahui prinsip check and balances pada dasarnya adalah prinsip ketatanegaraan yang menghendaki lembaga-lembaga negara memiliki kedudukan yang setara dan saling mengontrol satu dengan yang lainnya. Menurut Jimly Asshiddiqie, sebagai negara demokrasi suatu hal yang wajar untuk Indonesia menerapkan prinsip check and balances dalam penyelenggaraan pemerintahannya, bahkan sangat diperlukan untuk mencegah terjadinya penyalahgunaan kekuasaan oleh para penyelenggara negara ${ }^{16}$ (dalam hal ini mengontrol KPU RI dan Bawaslu RI).

\footnotetext{
${ }^{15}$ Putusan DKPP Nomor 31-PKE-DKPP/III/2019.

16 Jimly Asshiddiqie, "Konstitusi dan Konstitusionalisme Indonesia” dalam Sutan Sorik dan Dian Aulia "Menata Ulang Relasi Majelis Permusyawaratan Rakyat dan Presiden Melalui Politik Hukum Haluan Negara”, Jurnal Konstitusi 17 (2), 2020, hal. 378. DOI: https://doi.org/10.31078/jk1727
} 
e-ISSN : 2621-4105

Pada satu sisi, penulisan ini setuju bahwa penting kiranya ada mekanisme koreksi bagi Putusan DKPP. Hal ini sejatinya sudah muncul melalui Putusan MK Nomor 31/PUU-XI/2013. Dalam putusan MK tersebut, MK menyatakan bahwa putusan final dan mengikat DKPP tidak dapat disamakan dengan putusan final dan mengikat dari lembaga peradilan pada umumnya. Sifat final dan mengikat dari putusan DKPP haruslah dimaknai final dan mengikat bagi Presiden, KPU, KPU Provinsi, KPU Kabupaten/Kota, maupun Bawaslu dalam melaksanakan putusan DKPP. Adapun keputusan Presiden, KPU, KPU Provinsi, KPU Kabupaten/Kota, maupun Bawaslu adalah merupakan keputusan pejabat Tata Usaha Negara (TUN) yang bersifat konkrit, individual, dan final yang dapat menjadi objek gugatan di peradilan TUN. Apakah peradilan TUN akan memeriksa dan menilai kembali putusan DKPP yang menjadi dasar keputusan Presiden, KPU, KPU Provinsi, KPU Kabupaten/ Kota, maupun Bawaslu, hal tersebut adalah merupakan kewenangan peradilan TUN.

Penulisan ini pun menganalisis bahwa Putusan MK No. 31/PUU-XI/2013 telah memberikan implikasi yakni mengkoreksi kekuatan sifat final dan mengikat pada Putusan DKPP. Final dan mengikat Putusan DKPP tidak dapat disamakan dengan final dan mengikat dari lembaga peradilan, melainkan final dan mengikat yang setara dengan keputusan pejabat TUN. Dengan kata lain, level dari dari Putusan DKPP ini sejatinya adalah keputusan yang sebetulnya dapat menjadi objek dari TUN dalam PTUN. Sayangnya dalam UU No. 7 Tahun 2017 jika dilihat Pasal 458 ayat (13) UU No. 7 Tahun 2017 mengenai sifat putusan DKPP masih sama persis dengan Pasal 112 ayat (12) UU No. 15 Tahun 2011 yang bersifat final dan mengikat. Seharusnya jika pembentuk undangundang sudah menindaklanjuti Putusan MK Nomor 31/PUU-XI/2013, seharusnya terdapat hal yang berbeda dalam hal pengaturan DKPP di UU No. 7 Tahun 2017 terutama tekait dengan sifat putusan dan mekanisme bandingnya. Penulisan ini pun berpendapat bahwa penting kiranya terdapat mekanisme banding, karena menurut Putusan MK No. 31/PUU-XI/2013 kedudukan dari putusan DKPP adalah setingkat dengan Keputusan TUN yang berarti sehingga perlu ada tingkat selanjutnya bilamana ingin banding.

Adapun ketika pembentuk undang-undang menghasilkan norma seperti yang ada saat ini dalam UU No. 7 Tahun 2017 dimana Putusan DKPP tetap final dan mengikat maka peluang koreksi Putusan DKPP sejatinya tertutup. Walaupun hal bisa saja dianggap 
e-ISSN : 2621-4105

pembentuk undang-undang UU No. 7 Tahun 2017 tidak melaksanakan Putusan MK No. 31/PUU-XI/2013, namun nyatanya hal ini bukanlah kali pertama. Pembentuk undangundang pun pernah tidak melaksanakan Putusan MK dalalm kaitannya untuk Pemilu dalam Putusan MK Nomor 97/PUU-XI/2013. Hal yang terkenal dari Putusan MK tersebu adanya pemisahan rezim yakni rezim Pemilu dan rezim Pemerintahan Daerah (termasuk Pilkada di dalamya), namun banyak orang terlupa bahwa sebetulnya amar Putusan MK in adalah mengenai penegasan MK untuk melaksanakan sengketa hasil Pilkada. Realitas dampak dari Putusan MK Nomor 97/PUU-XI/2013 ini menjadi dipertanyakan ketika kondisi pada saat ini sengketa hasil Pilkada tetap dilaksanakan di MK, walaupun undangundang Pilkada menyatakan peran MK di sini hanyalah sementara. ${ }^{17}$

Lebih lanjut lagi, terkait dengan karena kondisi saat dimana Putusan DKPP RI masih bersifat final dan mengikat, karena Putusan MK No. 31/PUU-XI/2013 tidak dilaksanakan, maka hadirnya Kepres No. 34/P Tahun 2020, harus dimaknai sebagai keputusan administratif saja. Subjek hukum dalam Kepres No. 34/P Tahun 2020 bersifat konkret dan individual. Terkait keputusan ini, perlu diketahui bahwa keputusan semacam ini yang bersifat individual dan konkret dapat merupakan keputusan yang bersifat atau berisi penetapan administratif (beschikking) ${ }^{18}$ Apalagi jika dilihat lebih dalam hadirnya Kepres No. 34/P Tahun 2020 adalah sekedar "baju hukum" dari suatu putusan dalam hal ini Putusan DKPP Nomor 317-PKE-DKPP/X/2019. Dengan demikian ketika PTUN No. 82/G/2020/PTUN.JKT menilai kembali apa yang sudah diputuskan sejatinya sangat terlalu jauh.

\section{Kewenangan KPU RI dalam Menerbitkan Keputusan KPU No. 663/SDM.13- SD/05KPU/VII2020 yang Mengaktifan Kembali Anggota KPU RI}

Sebagaimana diketahui bahwa UU No. 7 Tahun 2017 mengatur banyak hal, termasuk tentang Penyelenggara Pemilu. Hal ini muncul karena UU No. 7 Tahun 2017 yang diundangkan pada tanggal 16 Agustus 2017 merupakan undang-undang yang bersifat kodifikasi. UU No. 7 Tahun 2017 merupakan undang-undang yang mengatur khusus mengenai kepemiluan sebagai wujud tindak lanjut dari putusan Mahkamah Konstitusi (MK) yakni Putusan MK No. 14/PUU-XI/2013 yang menyatakan bahwa mulai

\footnotetext{
${ }^{17}$ Maryadi Faqih, "Konstruksi Keyakinan Hakim Mahkamah Konstitusi Dalam Putusan Perselisihan Pemilukada”, Jurnal Konstitusi 10 (1) 2013, hal 124.

${ }^{18}$ Jimly Asshiddiqie, “Perihal Undang-Undang”, Jakarta: Konstitusi Press, 2006, hal. 9-10.
} 
e-ISSN : 2621-4105

tahun 2019 Pemilu dilaksanakan secara serentak antara Pemilihan Presiden dan Wakil Presiden dan Pemilihan Anggota DPR, DPD, dan DPRD.

Adapun dikarenakan perintah Putusan MK No 14/PUU-XI/2013 terkait penggabungan kedua jenis Pemilu tersebut, pada waktu itu pembentuk undang-undang selaras dengan Putusan MK tersebut mengkodifikasikan sejumlah undang-undang kepemiluan kedalam 1 (satu) naskah undang-undang. Undang-undang yang pada waktu itu subtansinya dikodifikasikan yakni UU No. 15 Tahun 2011, kemudian undang-undang mengenai Pemilu untuk memilih anggota DPR, DPD, dan DPRD yang diatur dalam Undang-Undang Nomor 8 Tahun 2012 tentang Pemilihan Umum Anggota Dewan Perwakilan Rakyat, Dewan Perwakilan Daerah, dan Dewan Perwakilan Rakyat Daerah (UU No. 8 Tahun 2012), dan terakhir Undang-Undang Nomor 42 Tahun 2008 tentang Pemilihan Umum Presiden dan Wakil Presiden (UU No. 42 Tahun 2008).

KPU dalam UU No. 7 Tahun 2017 tidak banyak berubah dari UU kepemiluan sebelumnya (sebelum terkodifikasi). Dalam UU No. 7 Tahun 2017 penguatan bagi lembaga KPU lebih ke penguatan dari sisi struktur. Bilamana struktur organisasi KPU dipahami keberadaan organisasi dari hulu hingga hilir, maka jajaran administrator utama Pemilu adalah postur KPU, KPU provinsi, KPU kabupaten/kota, PPK (Panitia Pemilihan Kecamatan) Panitia Pemungutan Suara (PPS), Panitia Pemilihan Luar Negeri (PPLN), Kelompok Penyelenggara Pemungutan Suara (KPPS), Panitia Pemungutan Suara Luar Negeri (PPSLN), dan Kelompok Penyelenggara Pemungutan Suara Luar Negeri (KPPSLN). Postur itu tidak berbeda jauh dibandingkan dengan kelembagaan Pemilu sejak reformasi bahkan Pemilu semasa Orde Baru. Penguatan KPU dalam UU No. 7 Tahun 2017 KPU terlihat dalam postur organisasi KPU yang jika dibandingkan dengan Pemilu tahun 2014 adalah menyangkut jumlah komisionernya. Pembentuk undangundang pada waktu itu melihat event Pemilu 2019 sebagai Pemilu yang sama sekali berbeda karena keserentakannya. Untuk itu jumlah komisioner KPU di beberapa tingkatan ada yang ditambahkan dan ada yang disesuaikan. ${ }^{19}$

Ketika penguatan UU No. 7 Tahun 2017 bagi KPU hanya pada sisi strukutur maka hal menarik muncul ketika KPU dalam menerbitkan Keputusan KPU No. 663/SDM.13SD/05KPU/VII2020 dalam rangka pengaktifan kembali anggota KPU dalam hal ini Evi

\footnotetext{
${ }^{19}$ Achmadudin Rajab, "Perubahan Undang-Undang Nomor 7 tahun 2017 Sebagai Momentum Desain Ulang Lembaga Penyelenggara Pemilihan Umum”, Pemateri dalam Acara BPHN tanggal 13 Agustus 2020 berjudul Desain Ulang Lembaga Penyelenggara Pemilihan Umum.
} 
e-ISSN : 2621-4105

Nodiva Ginting kembali menjadi Anggota KPU kembali. Jika dilihat Pasal 13 mengenai kewenangan KPU tidak ditemukan kewenangan KPU mengangkat kembali anggota KPU, yang ada justru di Pasal 13 yakni pada huruf i UU No. 7 Tahun 2017 yakni mengangkat, membina, dan memberhentikan anggota KPU Provinsi, anggota KPU Kabupaten/Kota, anggota PPLN. Tidak ada disebut anggota KPU RI bisa mengaktifkan kembali anggota KPU RI. Jika menggunakan persepsi argumentum a contrario, maka sebetulnya tidak ada kewenangan KPU untuk itu. Hal ini sangat bertentangan dari sisi Hukum administrasi negara berdasarkan pendapat pakar Kusumadi Poedjosewojo dimana negara sebagai penguasa seharusnya menjalankan usaha-usaha untuk memenuhi tugasnya. Hal ini juga menurut penulisan ini tidak bisa dijadikan sebagai diskresi bagi Ketua KPU karena menurut Undang-Undang Nomor 30 Tahun 2014 tentang Administrasi Pemerintahan tepatnya di Pasal 1 angka 9 dinyatakan bahwa Diskresi adalah "keputusan dan/atau tindakan yang ditetapkan dan/atau dilakukan oleh pejabat pemerintahan untuk mengatasi persoalan konkret yang dihadapi dalam penyelengaraan pemerintahan dalam hal peraturan perundang-undangan uang memberikan pilihan, tidak mengatur, tidak lengkap, atau tidak jelas, dana tau adanya stagnansi pemerintahan".

Diskresi adalah "suatu kekuasaan atau wewenang yang dilakukan berdasarkan hukum atas pertimbangan dan keyakinan serta lebih menekankan pertimbanganpertimbangan moral dari pada pertimbangan hukum". ${ }^{20}$ Jikalau pelaksanaan pengaktifan anggota KPU RI tersebut dianggap sebagai bagian dari diskresi maka hal tersebut adalah keliru, karena dari sudut pandang hukum administrasi negara terdapat asas-asas hukum administrasi negara salah satunya asas yuridikitas (rechtmatingheid) bahwa stiap tindakan penjabat administrasi negara tidak boleh melanggar hukum harus sesuai dengan rasa keadilan dan kepatutan). Kewenangan tersebut bisa saja ditambahkan menjadi keweanangan KPU RI hanya dengan perubahan UU No. 7 Tahun 2017 terlebih dahulu. Momen saat ini adalah momentum yang tepat, jika saja kewenangan tersebut dirasakan penting, karena dalam Program Legislasi Nasional (Prolegnas) Prioritas Tahun 2020 terdapat judul Rancangan Undang-Undang (RUU) yang sejatinya perlu dirampungkan yakni RUU tentang Perubahan Atas UU No. 7 Tahun 2017. Judul RUU ini termasuk 1 (satu) dari 37 (tiga puluh tujuh) judul RUU yang ada dalam Prolegnas Prioritas. ${ }^{21}$ Adapun

${ }^{20}$ M. Faal, "Penyaringan Perkara Pidana Oleh Polisi (Diskresi Kepolisian)". Jakarta: Pradnya Paramita. Jakarta, 1991, hal. 23.

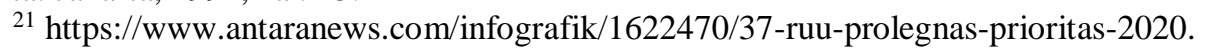


e-ISSN : 2621-4105

jumlah RUU dalam Prolegnas yang tidak terlalu banyak dibandingkan periode DPR sebelum-sebelumnya merupakan salah satu upaya DPR dan Pemerintah agar terus dapat mendapatkan kepercayaan dari masyarakat dalam pembentukan undang-undang. ${ }^{22}$

\section{E. PENUTUP}

Berdasarkan uraian dalam pembahasan di atas, maka dalam bab Penutup ini, terdapat simpulan yang menjawab permasalahan yang ada dalam bab pendahuluan. Bahwa terkait terkait dengan Putusan PTUN No. 82/G/2020/PTUN.JKT yang Membatalkan Kepres No. 34/P Tahun 2020 hal ini jelas sudah diluar dari keweangan PTUN. Karena Kepres No. 34/P Tahun 2020 sejatinya hanya menjalankan hasil Putusan DKPP dalam hal ini Putusan DKPP Nomor 317-PKE-DKPP/X/2019 yang pada pokoknya menjatuhkan sanksi pemberhentian tetap terhadap Evi Novida Ginting Manik (Komisioner KPU RI). Ketika muncul Putusan PTUN No. 82/G/2020/PTUN.JKT hal ini justru menurut pembahasan dalam penulisan ini merupakan produk hukum yang justeru menimbulkan ketidakpastian hukum. Dengan demikian terkait kewenangan Komisi Pemilihan Umum dalam menerbitkan Surat Keputusan KPU No. 663/SDM.13SD/05KPU/VII2020 dalam rangka pengaktifan kembali anggota KPU dari sisi hukum administrasi negara, hal ini juga tidak sesuai dengan kewenangannya, apalagi jika menggunakan persepsi argumentum a contrario, maka sebetulnya tidak ada kewenangan KPU untuk itu. Sebagai seorang pejabat Tata Usaha Negara penting kiranya Ketua KPU selalu mengambil langkah yang sesuai dengan koridor hukum dan peraturan perundangundangan.

\section{DAFTAR PUSTAKA}

\section{Buku}

Ali, Mahrus, "Dasar-Dasar Hukum Pidana”, Jakarta: Sinar Grafika, 2012.

Asshiddiqie, Jimly, "Perihal Undang-Undang”, Jakarta: Konstitusi Press, 2006.

Budiharjo, Miriam, "Dasar-Dasar Ilmu Politik”, Jakarta: Gramedia, 2008.

Faal, M., "Penyaringan Perkara Pidana Oleh Polisi (Diskresi Kepolisian)". Jakarta:

Pradnya Paramita, Jakarta, 1991.

Huda, Ni"ematul dan Imam Nasef, "Penataan Demokrasi dan Pemilu Pasca Reformasi", Jakarta: Kencana, 2017.

Soekanto, Soerjono. “Pengantar Penelitian Hukum”, Jakarta: UI-Press, 1986.

22 Muh. Risnain, "Konsep Peningkatan Kuantitas dan Kualitas Program Legislasi Nasional: Rekomendasi Konseptual dan Kebijakan Pada Prolegnas 2015-2019”, Jurnal RechtsVinding 4 (3), 2015, hal. 400. DOI: http://dx.doi.org/10.33331/rechtsvinding.v4i3.13 
e-ISSN : 2621-4105

Soekanto, Soerjono dan Sri Mamudji, "Penelitian Hukum Normatif: Suatu Tinjauan Singkat”, Edisi 1, Cet. V, Jakarta: PT RajaGrafindo Persada, 2001.

Georg, Sorensen, "Demokrasi dan Demokratisasi”, Yogyakarta: Pustaka Pelajar, 2003.

Soeroso, R., “Pengantar Ilmu Hukum”, Jakarta: Sinar Grafika, 2011.

\section{Jurnal}

Alfiantoro, Handoko, "Sentra Penegakan Hukum Terpadu Dalam Konsep Sistem Peradilan Pidana Pemilu”, Jurnal Ashyasta Pemilu 5 (4), 2018.

Achmadudin Rajab, "Kekuatan Putusan DKPP Sebagai Peradilan Etik Dalam Kerangka Restoratif Justice Pasca Putusan Mahkamah Konstitusi Nomor 115/PHPU.DXI/2013 Dan Putusan Mahkamah Konstitusi Nomor 31/PUU-XI/2013”, Jurnal Etika dan Pemilu 1 (2), 2015.

Agustino, Leo,et.al., "Poltik Lokal di Indonesia: Dari Otokratik Ke Reformasi Poltik", Jurnal Ilmu Politik 21, 2010.

Chakim, M. Lutfi, "Desain Institusional Dewan Kehormatan Penyelenggara Pemilu (DKPP) Sebagai Peradilan Etik”, Jurnal Konstitusi 11 (2) 2014.

Eva Ditayani Antari, Putu, "Implementasi Fungsi Pengawasan Dewan Perwakilan Rakyat Dalam Upaya Memperkuat Sistem Presidendsial Di Indonesia”, Jurnal Ilmu Hukum 4 (2), 2020.

Faiz, Pan Mohamad, “Teori Keadilan John Rawls”, Jurnal Konstitusi 6 (1), 2009.

Faqih, Maryadi, "Konstruksi Keyakinan Hakim Mahkamah Konstitusi Dalam Putusan Perselisihan Pemilukada”, Jurnal Konstitusi 10 (1), 2013.

Feriyani, Nora, "Analisis Yuridis Terhadap Putusan Dewan Kehormatan Penyelenggara Pemilu Bagi Komisi Pemilihan Umum Sebagai Penyelenggara Pemilu”, Badamai Law Journal 4 (1) 2019.

Hutapea, Bungasan, “Dinamika Hukum Pemilihan Kepala Daerah Di Indonesia”, Jurnal Rechtsvinding 4 (1) 2015.

Lulu Kukuh Sekartadi, "Kewenangan Dewan Kehormatan Penyelenggara Pemilu (DKPP) Mengubah Keputusan Komisi Pemilihan Umum (KPU) Provinsi Jawa Timur (Study Kasus Putusan NO.74/DKPP-PKE-II/2013)”, Jurnal IUS 3 (8), 2015. DOI: http://dx.doi.org/10.12345/ius.v3i8.220

Nasef, M. Imam, "Studi Kritis Mengenai Kewenangan Dewan Kehormatan Penyelenggara Pemilu dalam Mengawal Electoral Integrity di Indonesia”, Jurnal Hukum Ius Quia Iustum 21, 2014.

Pratikno, "Calon Independen, Kualitas Pilkada dan Pelembagaan Parpol”, Jurnal Ilmu Sosial dan Ilmu Politik 10 (3), 2007.

Nazriyah, R., "Pemberhentian Antar Waktu Anggota KPU (Analisis Putusan Mahkamah Konstitusi No. 80/PUU-IX/2011)”, Jurnal Konstitusi 9 (4), 2012.

Risnain, Muh., "Konsep Peningkatan Kuantitas dan Kualitas Program Legislasi Nasional: Rekomendasi Konseptual dan Kebijakan Pada Prolegnas 2015-2019”, Jurnal RechtsVinding 4 (3), 2015.

DOI: http://dx.doi.org/10.33331/rechtsvinding.v4i3.13 
e-ISSN : 2621-4105

Sorik, Sutan dan Dian Aulia "Menata Ulang Relasi Majelis Permusyawaratan Rakyat dan Presiden Melalui Politik Hukum Haluan Negara”, Jurnal Konstitusi 17 (2), 2020. DOI: https://doi.org/10.31078/jk1727

Yani, Ahmad, "Analisis Konstruksi Struktural dan Kewenangan DPR dalam Fungsi Legislasi Berdasarkan Undang-Undang Dasar 1945", Jurnal Konstitusi 15 (2) 2018. DOI: https://doi.org/10.31078/jk1526

\section{Peraturan Perundang-Undangan}

Undang-Undang Nomor 15 Tahun 2011 tentang Penyelenggara Pemilihan Umum.

Undang-Undang Nomor 7 Tahun 2017 tentang Pemilihan Umum.

\section{Putusan Mahkamah Konstitusi}

Putusan Mahkamah Konstitusi Nomor 11/PUU-VIII/2010.

Putusan Mahkamah Konstitusi Nomor 14/PUU-XI/2013.

Putusan Mahkamah Konstitusi Nomor 31/PUU-XI/2013.

Putusan Mahkamah Konstitusi Nomor 97/PUU-XI/2013.

\section{Internet}

https://www.antaranews.com/infografik/1622470/37-ruu-prolegnas-prioritas-2020.

\section{Bahan yang Tidak Diterbitkan}

Bahan Presentasi Achmadudin Rajab "Perubahan Undang-Undang Nomor 7 tahun 2017 Sebagai Momentum Desain Ulang Lembaga Penyelenggara Pemilihan Umum”, Pemateri dalam Acara BPHN tanggal 13 Agustus 2020 berjudul Desain Ulang Lembaga Penyelenggara Pemilihan Umum. 